\title{
Housing Development and Urbanisation in China
}

\author{
Dan Luo , Shujie Yao and JianlingWang \\ University of Nottingham
}

\begin{abstract}
Rapid urbanisation and rising income have led to a strong demand for housing in urban China. However, housing development has been distorted by speculation, income inequality and lack of government support for low-cost houses. In recent years, house prices become so high, making the vast majority of urban residents unable to afford, whereas rich families are able to buy many and leave them vacant. Income inequality is a major cause for rising house prices, which, in turn, exaggerates income inequality further. This vicious relationship has caused social tension between the rich and the poor and unhappiness among the middle and low income groups. This paper discusses the factors responsible for the housing bubble in China and recommends appropriate policies to resolve this problem.
\end{abstract}

Key Words: Economic affordable housing, China, Inequality

\section{Introduction}

The Chinese economy has grown rapidly for more than 30 years since 1978, with its gross domestic product (GDP) growing at almost 10\% per year during 1978-2010 (NBS, 2010). Despite the world financial crisis and the worsening European debt crisis, China’s GDP still rose 9.2\% in 2011 (NBS, 2012).

Such rapid economic expansion has raised people's living standards and incomes enormously, triggering a rising demand for consumer goods in general and commercial housing in particular. A normal rise in housing demand and prices is healthy for the country's economic development and urbanisation. However, if house prices rise too rapidly, making houses unaffordable by the vast majority of the ordinary urban residents, it is a clear sign of housing bubble.

There are two detrimental consequences once the bubble becomes too big. First, it will exclude many ordinary people from the housing market, generating a strong sense of unhappiness among the population. Second, once the housing market bubble 
bursts, it may bring China into a deep financial crisis and jeopardise its long term ambition to become a world economic superpower in the future.

Starting from the second half of 2009 when the turbulence caused by the collapse of the Chinese stock market and the world financial crisis has yet been fully arrested, another round of economic bubble originated from China's property market started to emerge. Although the central government adopted various methods to cool the market down, the monthly growth rate of sales prices of 70 large- and medium-sized cities remained at a high level of more than 12\% from March to May 2010.

The housing market bubble was fuelled by the so-called 'land kings' (single pieces of land sold at ridiculously high and record-breaking prices) in Beijing and other major cities throughout the country. Before the 2010 Chinese Spring Festival, hundreds of thousands of rich Chinese flew to Hainan Island to queue for buying any houses available there. Overnight, the cost of a hotel room in Sanya City at the south end of the Island went up to over RMB 30,000 for one night, while the normal price was about RMB 1000-3000 per night. House hunters offered prices doubling, or even tripling the existing level within weeks. In Hangzhou, some developers raised the selling price of new houses by RMB 4000 per squared-metre in one day. The incremental price on top of the local average price of RMB 15,000 per squared-metre was truly shocking to anyone in and outside China.

By March 2010, house prices in some large Chinese cities were as high as, or even higher than those in the major cities outside London in the UK, but per capita GDP of China was only one-eighth that of the UK. This level of house price is obviously unsustainable in China. It was this alarming situation that triggered the central government to issue a series of regulations in the following months, aiming at appeasing the market, each more aggressive than the other.

The latest policy required buyers for a second home to have a down payment worth $50 \%$ of the house value and pay an interest rate 1.1 times the normal market rate. It also urged commercial banks not to lend to those buying a third house. From May 2011, the central government ordered all the main cities throughout China to restrict the numbers of houses each household could buy. 
The sincerity and seriousness of such policy suggested that without government intervention, the Chinese housing market would run out of control with unforeseen devastating consequences. Thanks to these policies, house prices have been stabilised but at the cost that house sales has declined sharply in some major cities. In the first 9 months of 2011, housing stock accumulated to over 45 million squared-metres in 8 large cities, and house sales declined by $44 \%$ in September alone (Caijing, 2011).

The overheating housing market and the unusual government policies to cool down the market spark our research curiosity to explore the true nature of housing market development in China. It is imperative to understand the history of the Chinese housing market and its key drivers for demand and supply. It is also important to know the extent to which the housing market bubble has been developing and the potential consequences of rising house prices and the bursting of the housing bubble.

Given the importance of housing in people's life, it has been argued that allocating houses to individuals who only enjoyed the living rights was one of the biggest wealth redistribution in China's post-1949 history before economic reforms ( $\mathrm{Li}, 2004)$. However, the old policy was considered to be highly inefficient for housing development. In addition, only a small proportion of the population had benefited from the system.

Hence, China has faced an important dilemma in its housing policy, that is, how to improve people's living space, but at the same time, make sure that low and middle income people are able to find affordable housing? Housing market reforms have encountered many new challenges, such as how to balance the development of lowcost (including rented) houses and commercial houses and how to balance housing demand and urbanisation?

To analyse these questions, this paper starts from reviewing the history of the Chinese housing market system from 1949, paying attention to housing market reforms after 1978. It will then examine the situation of the current housing market and how its development will meet China's long term goals of urbanisation and the establishment of a harmonised society. It will compare the house prices in China and those in other 
countries to see whether there is a housing market bubble in the making. Finally, it will make some policy recommendations for China's future housing development over the next 20 to 30 years. A few scenarios of house construction and urbanisation will be presented to see when and how China may be able to achieve its long term development goals. The research results are not only important for understanding the Chinese housing issue at present but also help us design some useful policies for the country in the future.

\section{Review of the Chinese Housing System}

\subsection{Housing market prior to economic reforms (1949-78)}

A Soviet-style Chinese urban housing market was established in 1949. Along with land reform, urban lands were nationalised and owned by local governments who were empowered to allocate lands to various state-owned bodies, such as state-owned enterprises (SOEs), administrative organisations and public institutions (Wang and Murie, 1999). In the 1950s and 1960s, private houses in urban areas were gradually transferred to local governments. In the meantime, the government built large quantities of public housing through industrial expansion and urban renewal programmes (Wang, 1995). Housing was regarded as welfare provision to state employees, often through their work units such as SOEs and government agencies.

This housing system had two important features. First, the state through its agents made decisions and regulations on investment, management, allocation and control of houses. Second, rent incomes (very low) were used to support maintenance and further development. This system had many problems. It neglected the role of market. The floor space allocated to state employees did not depend on their performance but on their job rankings, length of services, household size and profitability of enterprises. Meanwhile, different work units were also treated differently. Larger work units with higher administrative ranking and producing crucial products for the state, provincial, or municipal plans had larger funds available for housing construction. For smaller or collective work units, they could not afford to build enough houses for their employees who then had to rely on private or municipal housing which was of low quality and small (Walder, 1986). 
Data from the NBS shows that although per capita floor space of residential building in urban China improved to $7.6 \mathrm{~m}^{2}$ in 1978 , in some big cities, such as Haerbin and Guangzhou, per capita floor space remained as low as $2.93 \mathrm{~m}^{2}$ and $1.5 \mathrm{~m}^{2}$ respectively (Zhang, 2009). Inequality and non-transparent land allocation and inadequate rents impeded further housing construction and consequently imposed a heavy burden on work units. Combined by accelerated economic development and rapid rise in urban population, drawbacks of such welfare housing system became ever more apparent, leading to its full abolition in the late 1970s.

\subsection{Housing reforms from 1978}

In accordance with China's economic reform, its market-oriented housing reform had also been implemented, aiming at increasing efficiency in the overall investment, construction and allocation processes. The whole reform during the past 30 years could be roughly divided into four stages.

The first sub-period 1978-88 witnessed the gradual sales of existing public housing to state employees along with an acceleration of urbanisation. In the early 1980s, Beijing Property Development Company was established and a series of new housing policies was initiated by the government, such as the "third-third management system (san-san zhi)": existing or newly built public houses were sold to state employees but three different parties, employees, enterprises and government, was each responsible for one-third of the construction cost (Zhou and Logan, 2002).

The new system enabled the work-units to withdraw from direct housing construction and urban development was centrally controlled by the government under the principle of "six integration (liu tong yi)": integration in planning, investment, design, construction, distribution and management (Wang and Murie, 1999). Consequently, large scale integrated urban development projects were implemented.

However, at this stage, housing was still heavily subsidised by enterprises as urban incomes remained low. Worse more, some local governments transferred their duties to the work-units and consequently made it almost impossible for small and private 
firms to build houses for their employees. Nevertheless, for some SOEs operating in favourable economic sectors with high profitability, sufficient funds were provided to assist their employees for house purchasing. Such arrangement caused severe inequality in house distribution, posing a heavy burden on the work-units. In 1986, the central government issued related policies to prohibit discounted public housing transaction and since then, urban public houses were sold at full price (Li, 2007).

The second stage of housing reform was during 1988-98 along with land reform. It was the first time when ownership of state-owned land was allowed to be sold to private individuals in China for up to 70 years $(\mathrm{Wu}, 2001)$. Under the new system, land ownership structure had not been changed but local governments were given the authority to acquire and sell land ownerships fixed for 70 years to developers. Three methods, negotiation, invited tendering and auction, were proposed to auction for land ownerships (Wang and Murie, 1999). However, the actual impact of the change was quite limited as most land was still leased via negotiation rather than auction (Yeh and $\mathrm{Wu}, 1996)$.

During this period, housing reform was directed at replacing the in-kind housing allocation with a monetized housing distribution system. Through raising rental cost, enhancing household incomes and increasing housing subsidies, the government tried to encourage private house purchasing ( $\mathrm{Li}, 2007)$. A number of preferential policies, such as "strive to develop affordable housing" and "giving permission to sell purchased old public houses in an open market after five years ownership" were issued to stimulate demand. During Xiaoping Deng’s 1992 southern tour, he iterated the determination of the government to establish a full market-oriented housing system with more houses being built for the low- and meddle-income families. Thereafter, investment in housing development surged. In 1992 and 1993, the growth rate of investment in real-estate development reached $117.6 \%$ and $165 \%$ respectively, while the GDP growth rates were $14.2 \%$ and $13.5 \%$ respectively over the same period (Zhang, 2008). Such fast expansion caused serious inflation, resulting in the first country-wide housing boom in late 1993.

To cool down the over-heated housing market, the Chinese government implemented a series of adjustment approaches, pushing the housing reform to a new stage. In 1994, 
the first real-estate legislation, "China Urban Housing Management Law" was passed in the eighth National People's Congress, setting up the basic rules for China's realestate industry. In the same year, the State Council published "Several opinions on deepening the urban housing system reform", emphasising the strategic importance of the real-estate industry in the overall economy.

In 1995, the "Comfortable Housing Project (anju gongcheng)" was lunched to provide affordable housing to low- and middle-income families as houses were required to be sold at construction costs. Meanwhile, collective house construction by work-units and employees were encouraged. Although the policy was criticized for causing problems in fund collection, construction standard unification and property right allocation, it greatly helped improve the housing condition of urban households. Since then, the government started to build up a multi-level housing system which aimed at protecting the interests of those economically disadvantaged groups by offering them houses with social security nature, while for people with higher income, they had to buy commercial houses from the market at higher prices.

In the meantime, the housing provident fund was set up to facilitate house construction and consumption (Zhang, 2008). Thereafter, the Chinese housing market experienced a relatively healthy expansion until 1997, when the real-estate industry was hit by the Asian financial crisis badly.

The third stage of housing reforms started from 1998. The central government implemented a series of new policies to further transform the old housing system. The main reform during this period was to classify households into three different categories as income distribution in China became highly polarised.

Based on the classification of households, three kinds of houses were proposed to be built: low-rent housing for low income households, economic and affordable housing for middle income households and commercial housing for rich households. The first two kinds of houses required different levels of state subsidies while the latter type was intended to be sold at full market price. This policy sound very reasonable and attractive but when it was actually implemented, two big problems emerged. First, it was very difficult to classify households into different income groups. As a result, 
low-rented and economically affordable houses were not necessarily allocated to the neediest families. Rampant corruption at the local levels often exacerbated unfairness in the house allocation system. Second, as low-rented and low-cost housing were highly unprofitable compared to commercial housing, developers were more willing to build commercial houses although this might violate state regulations.

After the Asia financial crisis, house construction was selected to become a national pillar industry. In July 1998, the State Council issued "The notice of further deepening urban housing reform and accelerating housing construction", clearly stating that the welfare housing system characterised by in kind allocation would be abolished and replaced by a full functioning real-estate market by the end of the year (Feng and $\mathrm{Ni}$, 2009). Under the new policy, newly started floor space in 1998 alone reached 203.9 million $\mathrm{m}^{2}$, up by $45 \%$ from the previous year. The growth rate of investments in housing was twice as high as that of GDP, increasing by 17\% per annum during 199803 (NBS, 2008).

The booming real-estate industry prompted a sharp rise of house prices. Developers exclusively focused their investments in profitable commercial housing, ignoring government's call for building "economically affordable housing" which was restricted to have a low profit margin of 3\%. From 1998 to 2003, the share of economic housing in newly started floor space for residential houses declined from $23 \%$ to $13 \%$ (NBS, 2008). Consequently, a large number of commercial houses had been built but remained too expensive for the low and middle income households.

In 2003, the State Council restated the importance of controlling house prices at an acceptable level and the necessity of building a sound housing security system. However, lack of control on the application and purchase of "economically affordable housing" and inadequate supply of "low-rent houses" made it difficult to solve the housing problem for the socially or economically disadvantaged groups. Rental incomes from low-rent housing were far from enough to support maintenance and construction, turning the profit-oriented real-estate developers away from building low-rent houses. 
The fourth stage of housing reform from 2006 started to put more emphasis on controlling house prices and offering more support to poor urban households. People eligible to purchase "economically affordable housing" were changed to low-income households only and house developers were required to increase the supply of smaller and low-cost houses. In the meantime, land supply was under the guideline of "limited selling price and habitable area" to enable real-estate developers to build 'price-limited' houses for middle income households.

In 2007, the State Council issued "Several opinions on solving the housing problem of low-income urban households" and founded the Department of Housing Security attached to the Ministry of Housing and Urban-rural Development (Feng and Ni, 2009). It was mainly responsible for formulating housing security related policies and managing the central fund for "low-rent housing" development. Such arrangement fully reflected the great importance attached by the central government on resolving the housing difficulty of the urban poor. Despite all these positive acts, issues related to more effective regulation of the real-estate market, in particular, land transaction and housing construction by developers remained unresolved.

\section{Current situation of China's commercial housing system}

\subsection{Chinese housing market after 30 years of reform}

After more than 30 years of reform, a comprehensive housing security system has been established, dominated by 'low-cost housing', 'price-limited housing' and 'lowrent housing'. Up to 2008, all the major cities in China have established the low-rent housing scheme, ameliorating the living condition of almost one million low-income urban households (Zhang, 2009). Meanwhile, the housing provident fund system has also been set up to assist employees to purchase commercial houses.

In 1978 when the economic reform started, per capita floor space of residential building in urban China was just 6.7 square meters. Thirty years later, this figure rose 
to 36.2 square meters by 2011 (Figure 1). ${ }^{1}$ Per capita floor space of residential building in rural China quadrupled during 1978-12, reaching 36.2 square meters (Figure 1).

Figure 1 Per capita living floor spaces in urban and rural China, 1982-2012 (m²)

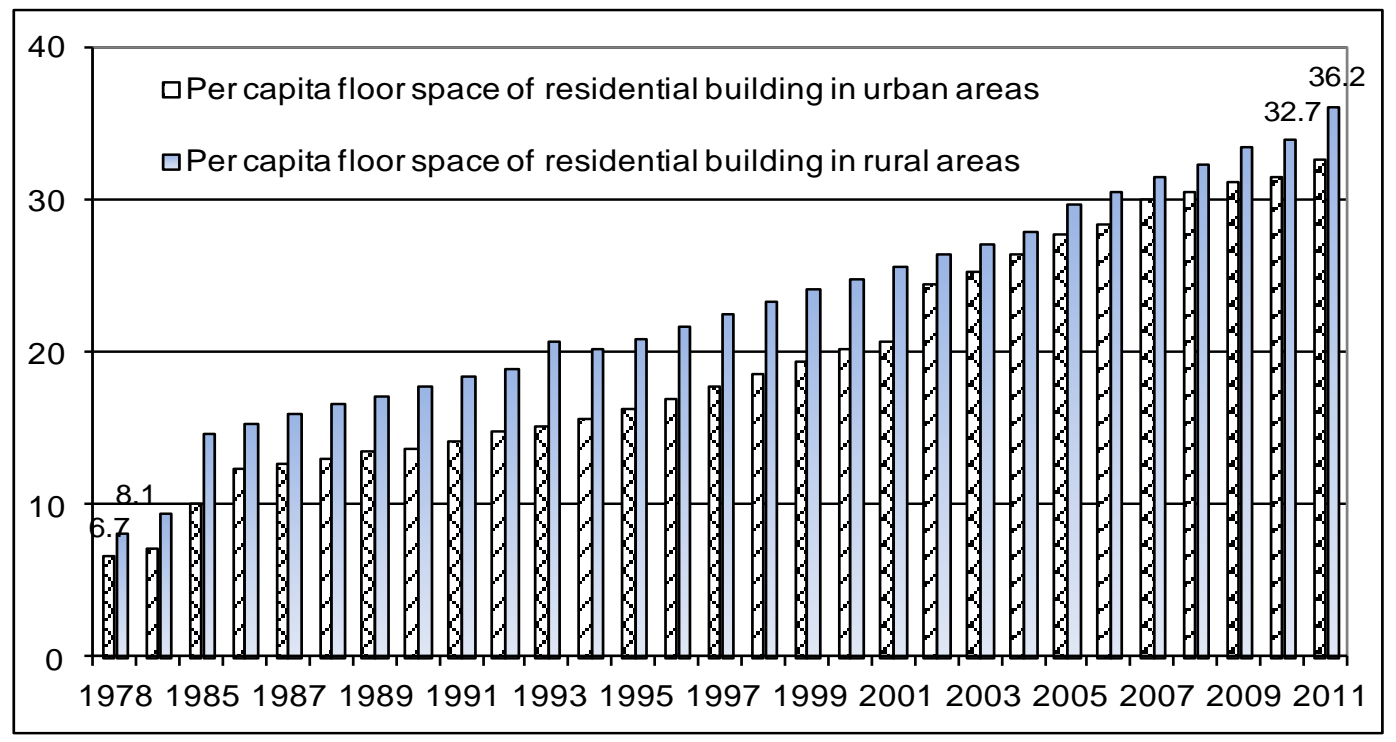

Source: NBS, 2012.

The real-estate industry has contributed significantly to China's economic growth. The growth of GDP and sales revenue of commercial housing were closely related to each other. In 2011, the value-added of the real estate industry was RMB 2.7 trillion, five times of the 2000 level. The average contribution of the real-estate industry was about $4.5 \%$ to GDP since the 1998 housing reform. If combined with the construction industry, they together contribute to more than $10 \%$ of GDP each year. The real-estate sector has also become an important recipient industry of foreign direct investment (FDI) in recent years. In 2000, real-estate development accounted for $8 \%$ of China's total FDI inflows. By 2011, this share jumped to 23\%, with the total amount of FDI absorbed by the industry more than tripling to $\$ 27$ billion.

\footnotetext{
${ }^{1}$ Based on author's calculation using the total floor space of residential building in urban area and number of urban populations in 2008 (National Bureau of Statistic), by 2008, the total floor space of entitled to each urban resident was about 28.4 square meters in average.
} 
Nevertheless, such drastic expansion also caused various side effects. The original thought of establishing an integrated system which provides multi-level housing targeting on buyers with different economic capacity was far from complete. In rural areas, house supply still mainly depends on self-construction, whereas in the urban areas, developers monopolize the market, forcing house buyers to accept whatever the price is on offer (Xue, 2009).

Average selling prices of residential buildings went up by almost 269\% during 19982011 in urban China. As China is such a large country, house prices vary enormously between cities. The selling price of residential buildings in 18 out of 31 provinces, municipalities and autonomy regions doubled during the period 2005-2011. While in Beijing, Zhejiang and Hainan, urban house prices rose as much as $152 \%, 147 \%$ and $218 \%$ respectively over the same period. Despite a flattering property sales and price in the first half of 2009 due to the world financial crisis, the market revived sharply in the second half of the year, inflated by the government's RMB 4 trillion stimulus package and RMB 9.6 trillion of new bank loans.

In addition, the housing provident fund system in China is also problematic, not only because of its insufficient coverage but also because of the low efficiency usage of funds. By the end of 2005, 63.3 million people in China had joined the system, with an accumulative fund of RMB 626 billion (Jia and Liu, 2007). However, only $45 \%$ of the fund was granted as housing loans while the rest was either deposited in banks or managed by professional fund management institutions.

\subsection{House price rise: a demand-supply analysis}

There is no doubt that rising house prices have created many social problems in China. Nevertheless, house price continued to rise and a large number of property development projects were being undertaken. People are curious about the impetus behind such enormous growth.

In terms of demand, housing has always been a scarcity product due to a large population base and rapid urbanization in China. According to the sixth population census, urban population accounted for $49.7 \%$ of China's total population of 1.34 
billion in 2010. This share rose to $52.6 \%$ by 2012 . Out of the urban population, however, 260 million were non-registered (Hukou) residents, who were mainly ruralmigrant workers living in cities for at least six months with or without their families by the time of census. Over the same period, urban residential housing increased by 5.6 billion square meters, or 37 square meters for each new urban resident.

However, only one-third of these new buildings were commercial houses available to the general public, leaving just over 10 square meters of living space for each of the additional urban resident (China Statistical Yearbook, 2011). In addition, as wealthy households tended to buy two or more houses, the amount of floor space left for the low income groups became quite limited. This creates a fragmented demand market. On one hand, there is always a hunger for housing but the poor are excluded from the market due to rising prices. On the other hand, more and more houses are being built for the wealthy people who have every temptation to buy more and more houses in expectation of high investment returns.

Rising house prices have also been propelled by rapid household income growth. On average, house price inflation is lower than the growth rates of urban per capita disposable income and employees' earnings. As a result, the demand for housing, especially for high-quality housing, increased more strongly over time, prolonging the housing boom.

Another factor pushing up house demand is China's specific consumer behaviour. In China, the psychological difference between owning and renting a house is huge, and in most places, having a house is a pre-requisite for a boy to get married (Jia and Liu, 2007). House is not simply a place to live but a symbol of social status. Young people tend to buy houses before they get married. Middle aged and high income people tend to buy two or more than two houses for investment purposes and for their children, or even grandchildren.

China's homeownership is amongst the highest in the world. It reached $82 \%$ in 2008, compared to $65.6 \%, 69 \%, 55 \%, 60 \%$ and $40.5 \%$ respectively in the US, the UK, France, Japan and German (Dai, 2009). Houses are normally bought by young people who are heavily subsidised by their parents and grandparents, draining away lifelong 
savings of two or three generations. That explains why house prices are high and increasing at all times, resulting in exceptionally high price/earnings ratios.

The gradual change of household structure also contributes for rising house demand. In 2011, average household size was 3.07, down by 10\% from 3.42 in 2001 (NBS, 2009). Although the decline in household size is not large, given China's large population base, the number of households increased significantly. In 2008, there were 372 million households in China, which would be 37 million less had the average household size remained at its 2000 level. The household size in the urban areas declined much faster than that in the countryside. For instance, over the same period, the average household size in Beijing and Shanghai declined by $12 \%$ and $13 \%$ respectively.

Lack of investment channels is another reason for people to invest heavily in the housing market. Bank deposit rate was low and was unable to keep up with inflation, reducing people's incentives to make savings in banks. As investments in the stock markets had suffered enormous losses during 2007-08 and remained bearish since then, people were left with no choice but relying on the housing market for better returns (Yao and Luo, 2009).

During the past decade, the proportion of houses bought as hoarding and speculation has increased substantially. This is evidenced by a sharp rise in house prices and small increase in rental costs (Figure 2). Theoretically, increase in house prices should lead to a proportionally increased house rents, but the two indices display a clear and widening divergence from 2003 onwards. For instance, compared to 2003, house prices in 2004 increased by $9.7 \%$ but house rents rose by just $1.4 \%$. The divergence in the two indexes implies that people with multiple house ownership bought houses not for living or investment, but for speculation and hoarding.

Figure 2 Housing price and rent indices, 1998-2010 


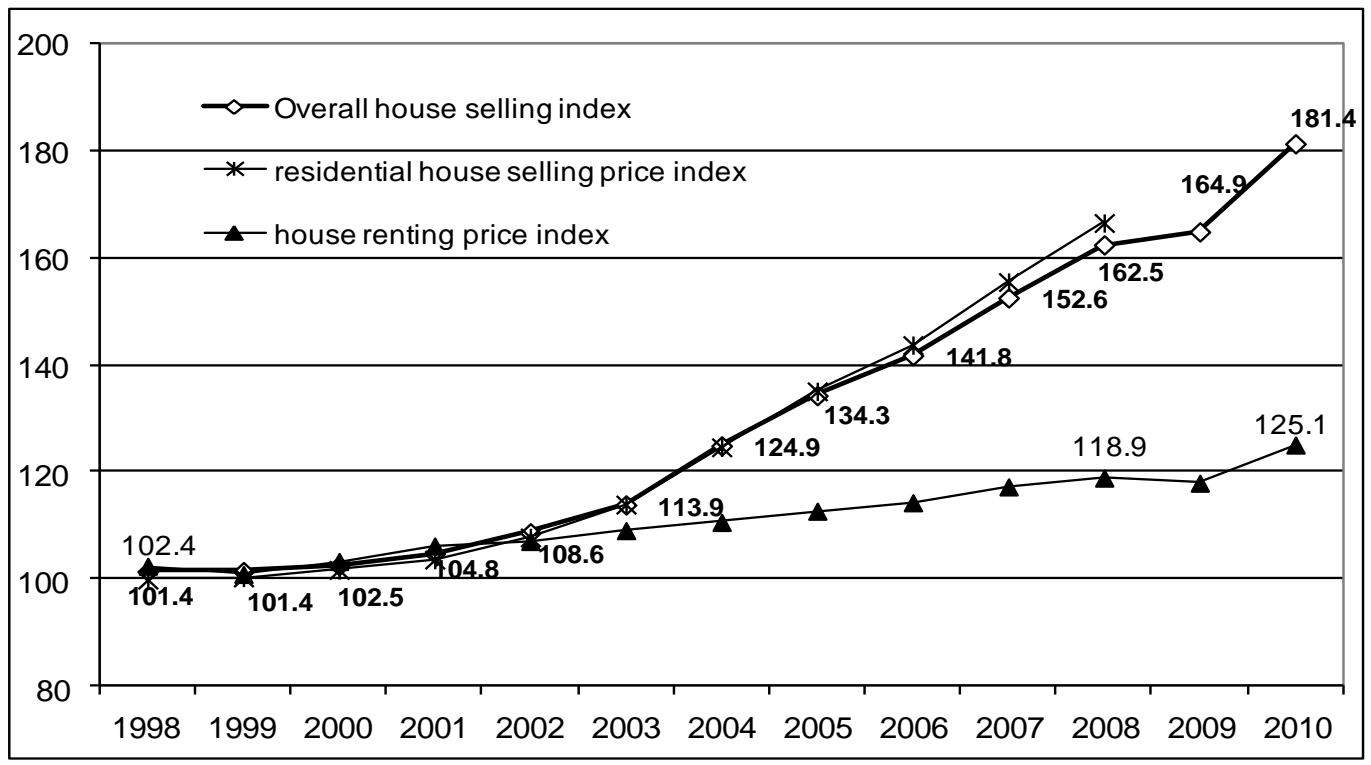

Source: National Bureau of Statistics (NBS).

Note: Prices in 1997 is used as base point.

On the other hand, some supply side factors also contributed to the inflating house prices. House price rise may have resulted from the collusion between local governments and property developers. Local governments favour high house prices because they reap huge revenues from land sales. Property developers like high house prices because they can achieve a large profit margin.

In general, house price consists of the costs of land, construction, taxes and fees, and profit. Since 1993, local government has taken all the revenue of land sales, which has become a huge incentive for local authorities to sell lands and raise land prices through auction. In 2001, land sales revenue amounted to RMB 130 billion, or 16.6\% of the total local revenue (Yuan, 2005; Dai, 2009). Land sales revenue rocketed to RMB 2.7 trillion in 2010, accounting for 67\% of local revenues (Figure 3). Despite being tightly controlled, income generated via land transfer was still account for about $60 \%$ of local governments' income in 2011. It is therefore obvious that the local governments are the biggest winners behind rocketing housing prices.

Figure 3 Land sales and local revenues, 2001-2011 (billion RMB and \%) 


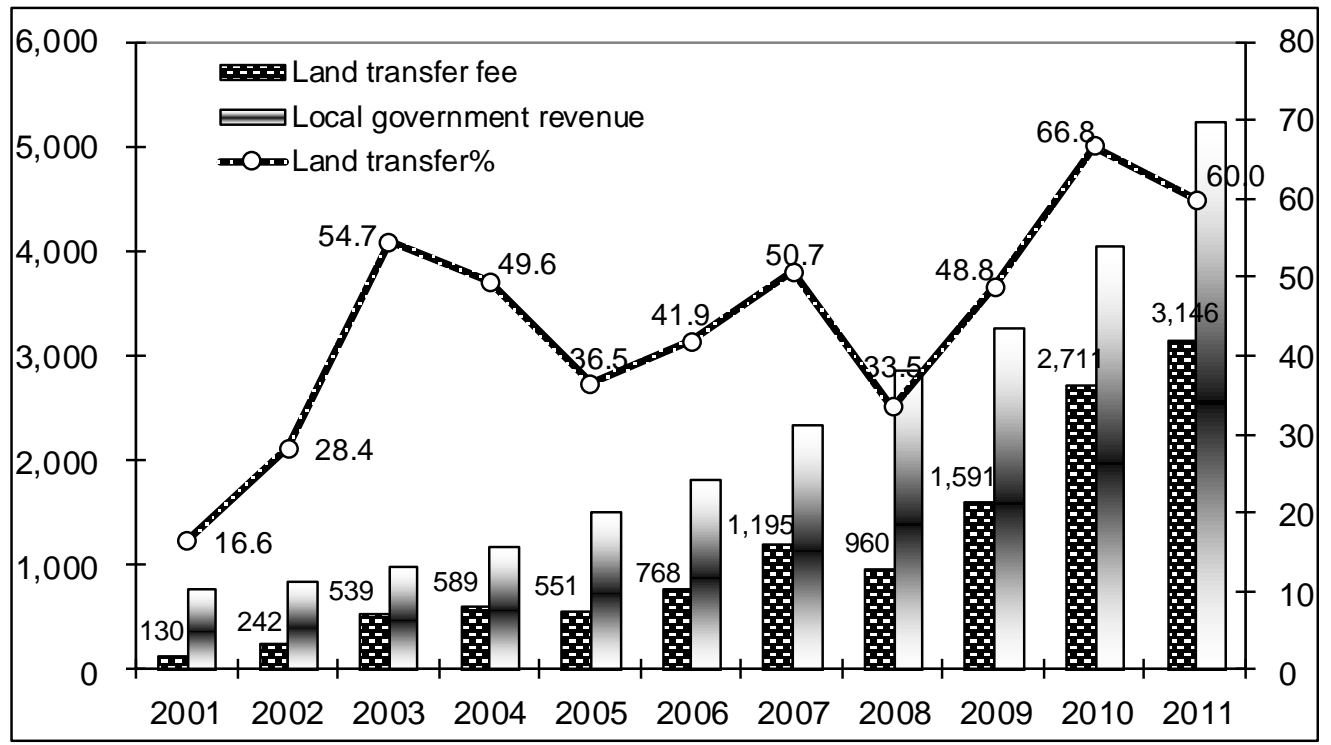

Source: Dai, (2009); National Bureau of Statistics (NBS, 2012).

Although several policies have been implemented to control land abuse and price boom, diverse interests between the central and local governments are hard to compromise. In 2009, land sales revenue increased by $63.4 \%$ to RMB 1.6 trillion, of which RMB 1.3 trillion, or $84 \%$ of total sales, came from the real-estate sector (NBS, 2010). By 2009, direct land cost accounted for $35 \%$ to $55 \%$ of house prices in different Chinese cities. In the US and other developed countries, this share is no more than 20\% (Wei and Wang, 2007; Yuan, 2003). This explains why house prices in China have been rising continuously and cannot be controlled by the central government.

\subsection{Beneficiaries behind and the widening gap in wealth distribution}

House rationing used to be a major social welfare policy in pre-reform China. Under the old system, only profitable large SOEs were able to provide limited living space for their employees. After the reforms, the house rationing system was gradually replaced with a new commercial housing system (Wang and Murie, 1999). All existing houses were sold at heavily discounted prices to their existing and legitimate occupants, i.e., state employees. Consequently, people who were assigned a public house before the reforms became the first group of house owners in China. Urban wages was simultaneously raised to reflect the cost of buying and renting houses. 
Although such company direct allocation and assisted house purchasing was officially stopped since 1998, houses with welfare nature selling at severely discounted price continued till the end of 2000 (Jian and Liu, 2007). Large SOEs, government organisations and the army were key players in the institutional housing market. As this group of people belong to the high income group, after they acquired cheap houses from their organisations, they can then save money to buy additional commercial houses. To a great extent, this distorted housing market explains why rich people can occupy two or more than two houses, pushing up house prices and hence excluding the poor from the housing market (Wang and Murie, 1999).

China's house provident fund, which was established to help people to buy houses, is also biased in nature. This fund is only available to registered formal urban employees who account for less than one-quarter of the total urban labour force. As a result, people who need help most are excluded from the system. The house provident fund effectively helps accelerate the divide between the rich and the poor in urban China.

Property developers in China can be best described as a mediator of the housing market. They obtain credits from banks and land from local authorities to build houses. They then sell houses to urban residents. Bankers, local authorities and properties developers share common interests, that is, profits. These three groups of people collude with each other to achieve the highest possible sales revenues from buyers. To do that, they have to create scarcity, complexity and opaqueness in the housing market so that monopolistic power can be fully exploited for profit maximisation at the expense of house buyers (Xue, 2007; Jian and Liu, 2007).

Finally, as the ultimate land owner and the only legal institution to acquire and sell lands, local governments are the biggest beneficiary of the booming housing market. Unlike in the western countries, houses sold in China do not involve the transfer of land ownerships, but the right to use for up to 70 years. Therefore, to maximise profit, the government on one hand slashes the agricultural land acquisition cost, while on the other hand charges high land leasing fees from the developers. Apart from selling lands, local governments levy more than 30 kinds of taxes and fees all the way through project approval to final inspection and acceptance relating to house construction and sales. All these charges in aggregate account for another 10-20\% of 
the house sale prices. Consequently, in total, local governments take over half of house sales revenue through land sales, taxes and fees (Wei and Wang, 2007).

In summary, transforming the in-kind housing allocation to monetary subsidies based on the housing provident fund is considered to be the most significant change to the old housing system in China. However, due to serious market imperfection and government interventions and control, not all the people have benefited from the reform. In effect, house market reforms have exaggerated the social inequality problem in China. SOEs employees, government officials, bankers and property developers are the main beneficiaries, whereas the poor and low income people are the biggest losers.

\subsection{China-specific housing supply and demand curve}

The previous sections explain various push and pull factors for rising house prices in China. Inequality of house ownership is closely associated with wealth redistribution and consequently leads to a deep division within the society. Figure 4 below shows the supply and demand curves under the normal condition where the whole population is relatively homogeneous.

Figure 4 Supply and demand curves for a homogeneous population

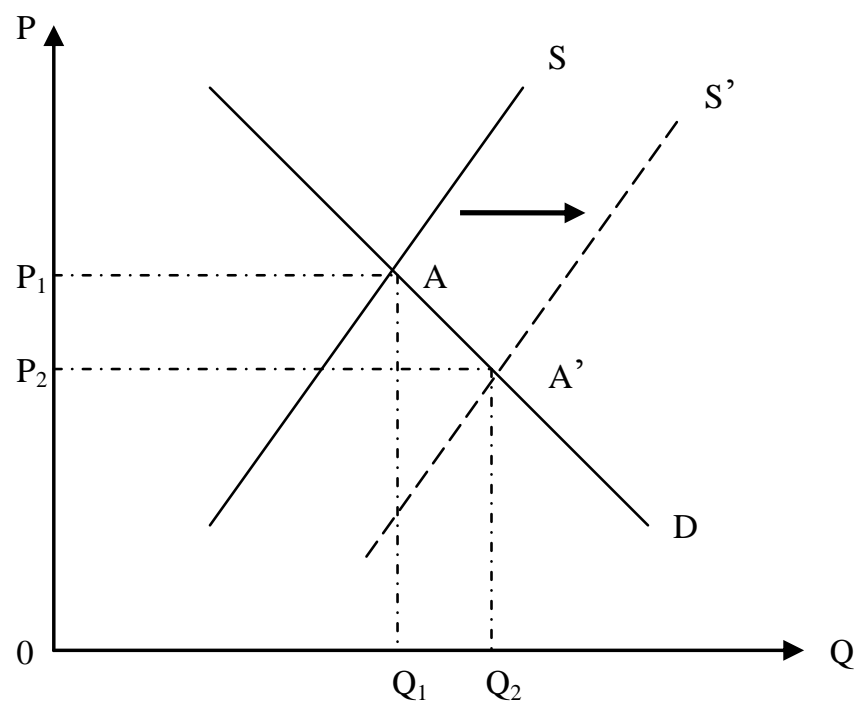

S and D represent house supply and demand curves, respectively. At equilibrium point $\mathrm{A}$, the market clearance price is $\mathrm{P}_{1}$ and the quantity demanded is $\mathrm{Q}_{1}$. If the 
government wishes to reduce market price, it can help move the supply curve to the right through providing more land for house construction, or relax various restrictions on property development. The market price could be brought down to $\mathrm{P}_{2}$ and house demanded increases to $\mathrm{Q}_{2}$ at point $\mathrm{A}^{\prime}$. This is a very simple but naïve solution to the problem of housing shortage with high prices.

As the Chinese urban population can be divided into the rich and poor classes, the population is heterogeneous and the house market can be represented by Figure 5 .

Figure 5 Supplies and demands of a heterogeneous population in urban China

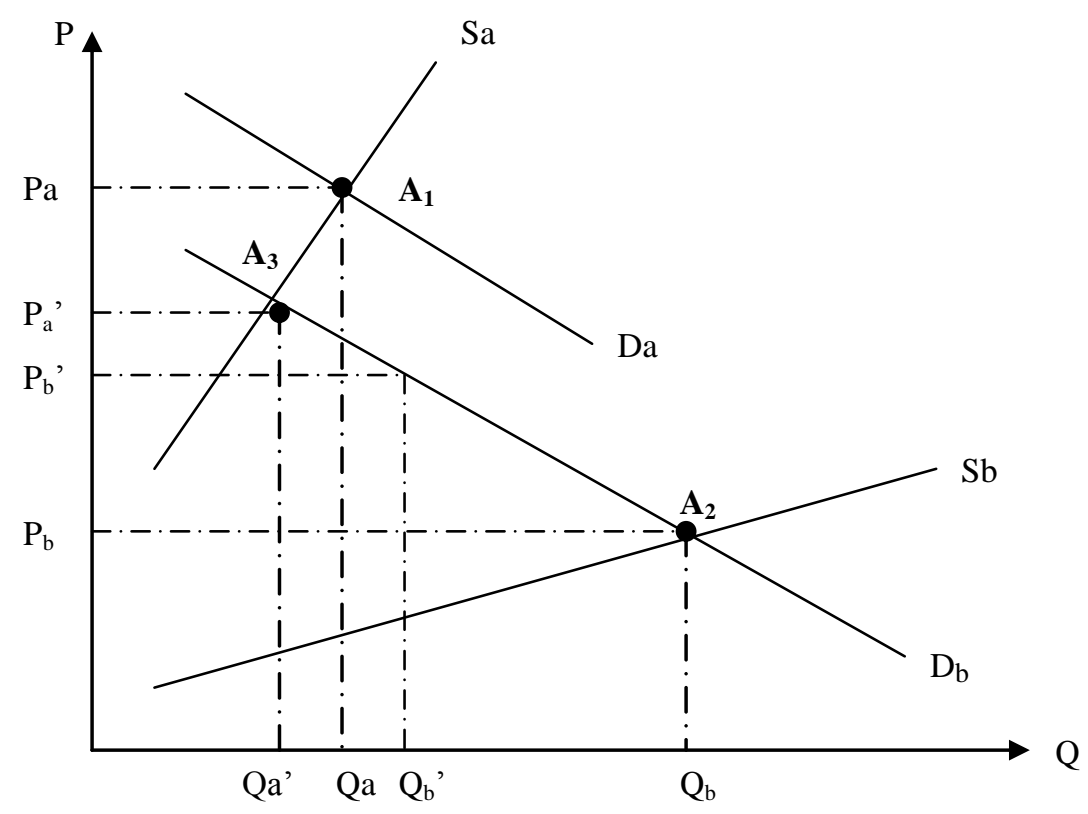

Assuming urban China has two divided housing markets: commercial housing for the rich and low-cost housing for the poor.

Sa and Da denote the supply and demand of commercial housing for high income households. At equilibrium, market price and demand are respectively Pa and Qa.

The vast majority of low and middle income households are totally excluded from the commercial housing market. They can only rely on low-cost housing. Sb and $\mathrm{Db}$ respectively denote the demand and supply of low-cost housing by middle and low income households. If there were sufficient supply of low-cost housing, the equilibrium price and demand of low-cost housing would be $\mathrm{Pb}$ and $\mathrm{Qb}$. As a result, 
despite the population being divided into two total different market segments, there would not be housing shortage and excessive pressure on price.

The trouble is that the supply of low-cost housing is highly unprofitable compared to commercial housing. Property developers only focus on building high-priced commercial housing and little effort (land and investment) has been made to construct low-cost housing. Assuming that low-cost housing supply is restricted to $\mathrm{Qb}$, there would be a shortage of (Qb-Qb') in low-cost housing, inducing an artificially high market price of such houses at $\mathrm{Pb}$ '.

Shortage of low-cost housing has the following consequences. First, many middle and low income households are not able to buy any houses. Second, prices of low-cost housing are artificially high. Third, if the selling prices of low-cost housing were capped at a level lower than $\mathrm{Pb}$ ' but still higher than $\mathrm{Pb}$, house buyers would tend to bribe housing officials to buy a low-cost house. Fourth, house shortage forces middle and low income households to buy commercial houses in a desperate attempt to gain a living space in the city. These four consequences explain why China's housing is always in short supply and why house prices have been unusually high by international standards.

\section{Household income and housing price}

\subsection{Income/price ratios of major countries}

Housing bubble is a type of economic bubble which appears periodically in local or global markets, notably in Japan in the early 1990s (Fackler, 2005) and the US after 2006. How to identify and prevent a housing bubble has been widely debated in the literature (Baker, 2002; Case and Shiller, 2003; Garber, 2000; Siegel, 2003).

Case and Shiller (2003) argue that unrealistic expectation of future price is the intrinsic reason for the formation of a housing bubble. However, how to define and identify a housing bubble is not an easy task. The following outlines a series of criteria to testify whether a bubble may exist.

- House prices rise sharply and continuously; 
- Investments in real-estate development accounts for a large share of total fixed-asset investment;

- Price/income ratio is high and rises continuously;

- Expenditure in housing to total household income ratio is high;

- Price/rent ratio is high.

Hit by the world financial crisis, the Chinese housing market also plummeted by more than $11.3 \%$ from 111.3 in January 2008 to 98.7 in March 2009, according to the index of house sales price of 70 large- and medium-sized cities. However, due to China's 4 trillion RMB stimulus package and 9.6 trillion RMB of new bank loans, house prices picked up rapidly since April 2009. Average sales prices rose by $24 \%$ in 2009, and another $16 \%$ during the first three months of 2010. In some cities, such as Beijing, Shanghai and Shenzhen, sales prices increased by more than $50 \%$ over the same period. The rapid growth of house prices triggers a hectic debate on whether there is a huge housing bubble being developed in China.

One important indicator for a housing bubble is an unusually high house price/household income ratio. According to the IMF, this ratio should be in the range of 1.8 to 5.5 in developed nations and about 3 to 6 in emerging economies (Wei and Wang, 2007). This ratio is well beyond the upper limits of the ranges in some major Chinese cities (Table 1).

Measured by the house price/household income ratio, house prices in China's main cities are significantly more expensive than some of the world's largest cities (Table 2). In the US and the UK, average house prices remained low in 2009 after the world financial crisis. It is worth noting that even for cities with the highest house prices in the UK and the US, none of them has a price/income multiple as high as that of Beijing or Shanghai.

Table 1 Household incomes, GDP and house prices, 2005 and 2008 (yuan and $\mathrm{m}^{2}$ )

\begin{tabular}{l|rr|rr|rr}
\hline & \multicolumn{2}{|c|}{ China } & \multicolumn{2}{c|}{ Beijing } & \multicolumn{2}{c}{ Shanghai } \\
Year & $\mathbf{2 0 0 5}$ & $\mathbf{2 0 0 8}$ & $\mathbf{2 0 0 5}$ & $\mathbf{2 0 0 8}$ & $\mathbf{2 0 0 5}$ & $\mathbf{2 0 0 8}$ \\
\hline GDP/head & 14,016 & 22,641 & 44,833 & 61,876 & 51,486 & 72,536 \\
Income/head & 10,493 & 15,781 & 17,653 & 24,725 & 18,645 & 26,675 \\
Household size & 3.1 & 3.2 & 2.7 & 2.6 & 2.7 & 2.6
\end{tabular}




\begin{tabular}{|c|c|c|c|c|c|c|}
\hline House price & 343,860 & 380,824 & 727,964 & $1,275,338$ & 782,209 & 972,617 \\
\hline Household income & 32,528 & 50,499 & 47,663 & 64,285 & 50342 & 69,355 \\
\hline Price/income ratio & 10.6 & 7.5 & 15.3 & 19.9 & 14.3 & 14.0 \\
\hline $\begin{array}{l}\text { Size/commercial } \\
\text { house }\end{array}$ & 117 & 107 & 118 & 110 & 117 & 120 \\
\hline \multirow[t]{3}{*}{ Size/low cost house } & 108 & 92 & 114 & 81 & -- & - \\
\hline & \multicolumn{2}{|c|}{ "Guangdong } & \multicolumn{2}{|c|}{ Hainan } & \multicolumn{2}{|c|}{ Xinjiang } \\
\hline & 2005 & 2008 & 2005 & 2008 & 2005 & 2008 \\
\hline GDP/head & 24,351 & 37,402 & 10,826 & 17,087 & 12,968 & 19,727 \\
\hline Income/head & 14,770 & 19,733 & 8,124 & 12,608 & 7,990 & 11,432 \\
\hline Household size & 3.4 & 3.4 & 3.8 & 3.8 & 3.5 & 3.5 \\
\hline House price & 463,045 & 648,795 & 408,230 & 500,789 & 143,964 & 200,244 \\
\hline Household income & 50,217 & 67,092 & 30,871 & 47,910 & 27,966 & 40,013 \\
\hline Price/income ratio & 9.2 & 10.1 & 12.3 & 10.5 & 5.1 & 5.0 \\
\hline $\begin{array}{l}\text { Size/commercial } \\
\text { house }\end{array}$ & 112 & 113 & 143 & 92 & 95 & 95 \\
\hline Size/low cost house & 107 & 107 & 252 & 95 & 89 & 95 \\
\hline
\end{tabular}

Notes: (1) House price $=$ sales revenue/number of houses sold. (2) House size is measured in squared meters $\left(\mathrm{m}^{2}\right)$. House size $=$ average number of people per household.

Sources: National Bureau of Statistics, 2006, 2009.

Table 2 Household incomes and house prices in China, US, UK

\begin{tabular}{|c|c|c|c|c|}
\hline 2009 & $\begin{array}{c}\text { Price } / \mathrm{m}^{2} \\
\text { (yuan) }\end{array}$ & $\begin{array}{l}\text { Price/unit } \\
\text { (yuan) }\end{array}$ & $\begin{array}{c}\text { HH income } \\
\text { (yuan) }\end{array}$ & Price/income \\
\hline China & 4,695 & 499,974 & 54,942 & 9.1 \\
\hline Beijing & 13,799 & $1,510,986$ & 69,942 & 21.6 \\
\hline Shanghai & 12,840 & $1,539,514$ & 73,282 & 21.0 \\
\hline Hainan & 6,264 & 576,293 & 52,126 & 11.1 \\
\hline \multicolumn{5}{|l|}{2010 (first half) } \\
\hline National average & 5,036 & 542,351 & 54,942 & 9.9 \\
\hline Beijing & 19,328 & $2,116,408$ & 69,942 & 30.3 \\
\hline Shanghai & 14,523 & $1,741,297$ & 73,282 & 23.8 \\
\hline Hainan & 9,267 & 852,604 & 52,126 & 16.4 \\
\hline \multicolumn{5}{|c|}{ US and UK, $2007-2009(\$)$} \\
\hline \multicolumn{5}{|c|}{\begin{tabular}{l|l|}
2007 &
\end{tabular}} \\
\hline UK & -- & 363,055 & 65,919 & 5.5 \\
\hline US & -- & 217,900 & 84,842 & 2.6 \\
\hline \multicolumn{5}{|l|}{2008} \\
\hline UK & -- & 313,476 & 62,417 & 5.0 \\
\hline US & -- & 196,600 & 86,858 & 2.3 \\
\hline \multicolumn{5}{|l|}{2009} \\
\hline UK & -- & 245,088 & 51,650 & 4.8 \\
\hline US & -- & 173,200 & 86,222 & 2.0 \\
\hline \multicolumn{5}{|c|}{ London and New York: $2008(\$)$} \\
\hline London & - & 516,865.1 & 84,765 & 6.1 \\
\hline New York & -- & 466,100 & 104,660 & 4.5 \\
\hline
\end{tabular}


Notes: For China, household income in $2009=$ household income in $2008 \times(1+$ average growth rate of household income in 2009). The figure in the first two months of 2010 is assumed to remain at the same 2009 level. Average household size and average house size were assumed to be unchanged in 2009 and 2010. The 2008 figure is based on the sales price of residential housing and the 2009 figure on the sales price of commercial housing, the difference is not significant. For UK, household income $=$ per capita household income $\times 2.4$ and for the US, household income=per capita household income $\times 2.6$.

Source: Data for China: National Bureau of Statistic (NBS); Data for UK: house price:

http://www.nationwide.co.uk/hpi/historical.htm; per capita disposable income:

http://www.euromonitor.com/United_Kingdom; household size:

http://www.statistics.gov.uk/cci/nugget.asp?id=2325; UK $£$ and US \$ exchange rate:

http://www.oanda.com/currency/historical-rates; Data for US: housing price:

http://www.census.gov/compendia/statab/cats/construction housing.html; per capita disposable income: http://www.euromonitor.com/factfile.aspx?country=US; household size:

http://factfinder.census.gov/servlet/ACSSAFFFacts? event=\&geo $\mathrm{id}=01000 \mathrm{US} \&$ geoContext=01000

US\&_street $=\&$ county $=\& \_$cityTown $=\& \_$state $=\& \_$zip $=\&$ lang $=$ en \& _sse $=$ on \&ActiveGeoDiv $=\&$ useE

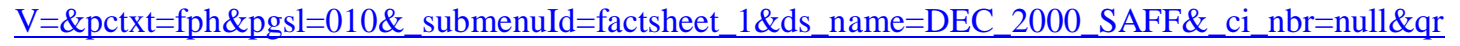
name $=$ null $\&$ reg $=\&$ keyword $=\&$ industry $=$.

Household investment in housing as a proportion of total income measures the propensity of consumer expenditure on housing. This is measured by the ratio of the sales revenue of commercial housing over the total income of urban residents. Taking into account of other living costs, this ratio should not be more than 30\% (Liu, 2007). However, as shown in Figure 6, after increasing steady for a few years, the ratio increased sharply in 2005 and approached the warning threshold in 2007. Despite moving downward slightly in 2008 , it bounced back sharply in 2009 , reaching $32 \%$. A rising proportion of urban incomes spent in housing is another indication of housing bubble because such a trend is unlikely to be sustainable.

The price to rent $(\mathrm{P} / \mathrm{R})$ ratio is defined as the average cost of ownership per square meter divided by monthly rental cost. A rapid increase in $\mathrm{P} / \mathrm{R}$ ratio implies a potential bubble. In a well-developed housing market, the general accepted P/R ratio should be 150-250 (Tang, 2009; An, 2008). However, in China, taking Beijing as an example, the average P/R ratio in 2009 was 383 (SouFun.com, 2009). In 2010, house price in Beijing rose further to RMB 16,431 per square meter in February, pushing the P/R ratio up to 456. In other cities like Shanghai, Shenzhen and Hangzhou, the P/R ratio ranges from 300 to 500 (Tang, 2009). It implies that currently, it would take a house buyer 33 years to fully recover the cost if the house were rented out all the time, far exceeding the generally accepted level of 16-21 years.

Figure 6 Household expenditure in housing and urban incomes 


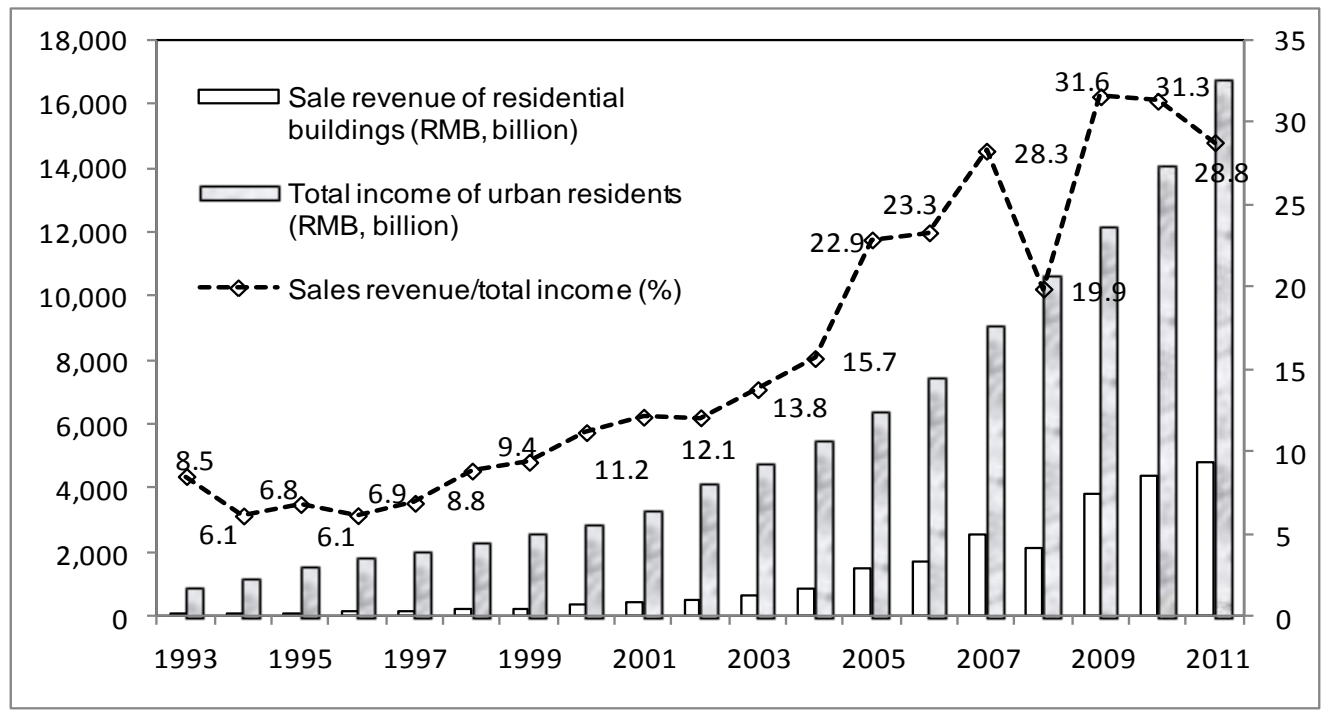

Note:

The sales revenue of commercialized buildings is used to represent the house sales price.

Source: National Bureau of Statistics, NBS.

In summary, all the above measures clearly suggest the existence of a potential bubble in the Chinese housing market. The national average house price may be overvalued by $100-200 \%$. The prices in large cities like Beijing and Shanghai could be overvalued by $300-400 \%$. Since 2008 , the price divergence between house price and construction cost has widened significantly, even after the implementation of a series of control policies by the government in 2010 (Figure 7). This pattern of divergence resembled that of the US housing market before it collapsed (Shiller, 2007).

Figure 7 How a potential housing bubble in China been built up

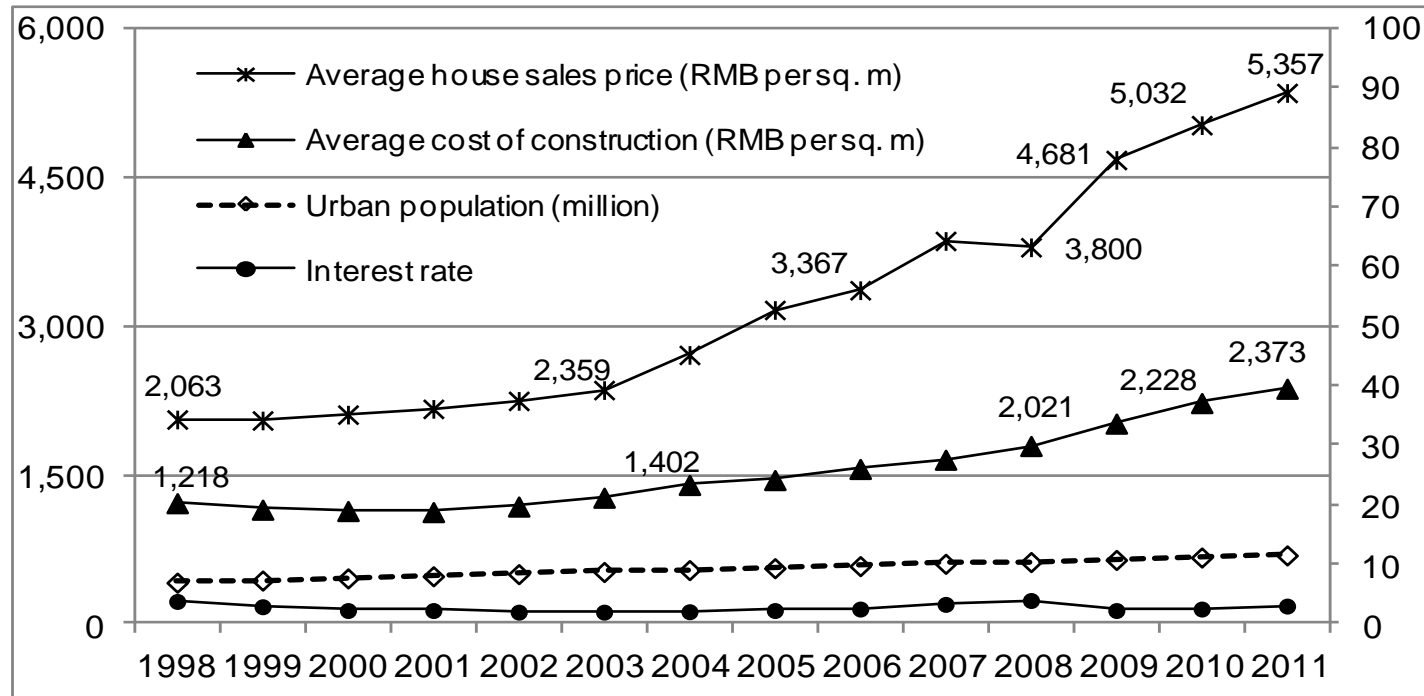

Source: National Bureau of Statistics, (NBS). 


\subsection{Chinese housing market: a dynamic equilibrium analysis}

The analysis in the previous sections shows a clear housing boom in China, but how long is this boom going to last? The following aims to construct a dynamic equilibrium model to testify when China may be able to meet its housing need and the pace of house construction to meet this target.

As proposed by the Ministry of Housing and Urban-Rural Development (MOHURD), under the general guidance of "building a moderately prosperous society in all respects", per capita building space in urban area should reach $35 \mathrm{~m}^{2}$ with the poorest having no less than $20 \mathrm{~m}^{2}$ by 2020 (MOHURD, 2004). Therefore in this paper, following the above criteria, "enough housing space" would be defined as $35 \mathrm{~m}^{2}$ per person. In addition, per capita floor space $(A)$ of $30 \mathrm{~m}^{2}$ will also be estimated for comparison.

Total stock of floor space, floor space completed each year, demolition rate and urban population growth rate are four basic variables of the model. Focusing on the urban areas, it is assumed that the total floor space at the end of the current year should equal to the total floor space at the end of the previous year plus the newly completed floor space in the current year minus the space demolished during the current year.

According to the China Statistical Year Book, the total floor space of residential buildings was 10,769 million $\mathrm{m}^{2}$ by the end of $2005 .^{2}$ The average annual growth rates of floor space completed $(\alpha)$ and urban population $(\mu)$ are assumed to be $6.7 \%$ and $3.0 \%$ respectively, consistent with their geometric mean over $2003-08 .^{3}$

It is more difficult to estimate the annual demolition rate $(\beta)$ of houses. Although the lease period of land used for residential buildings is 70 years, the designed useful life

\footnotetext{
${ }^{2}$ The figure, "stock floor space in urban China" disclosed in the latest accessible "Urban Housing Construction Statistics" issued by Ministry of Housing and Urban-Rural Development of the People's Republic of China in 2005 was 10,769 million sq. ms. This figure is consistent with the same data disclosed in China Statistical Year book and therefore we choose total stock floor space in 2005 as the base point.

${ }^{3}$ In 2003 , the real-estate industry was officially classified as a pillar industry and it has experienced rapid development since then. A higher annual growth rate of $10 \%$ for newly constructed floor space (from 2007 to 2008) each year and 3.5\% (over the period 2000 to 2008) for the increased urban population will also be estimated for comparison.
} 
of residential buildings is 50 years (MOHURD). This means that at least $2 \%$ of all residential buildings need to be demolished each year. However, a recent report by MOHURD suggests that the life expectancy of China's residential buildings is as low as 25 to 30 years (Wang, 6 April 2010). To reflect this, it is necessary to assume a higher demolition rate (e.g. $3 \%$ or $4 \%$ ) in the following calculation.

The final model is defined as follows:

$$
\text { TFS }_{t-1}+N F S_{t}-\text { DFS }_{t-1}=\text { POP }_{t} * A F S_{t}
$$

In equation (1), TFS denotes total floor space, NFS newly constructed floor space, DFS demolished floor space, POP population and AFS floor space per capita, $t$ current period and $(\mathrm{t}-1)$ the previous period.

In 2005, urban China had a total floor space of 10,769 million square meters, newly constructed floor space of 630 million square meters, a population of 577 million people. Let $\beta$ denote house demolition rate, $\alpha$ the growth rate of newly constructed floor space, $\mu$ population growth rate, then the following equation can be established, resulting in a dynamic relationship between AFS (floor space per capita) and $n$ (number of years) for both sides to be equalised.

$$
10,769 \times(1-\beta)^{i+1}+630 \times \sum_{i=0}^{n}(1+\alpha)^{i}(1-\beta)^{j}=A F S \times 577 \times(1+\mu)^{i}, \quad i+j=n
$$

Table 3 presents a few possible scenarios through setting different sets of values for the $\alpha, \beta$ and $\mu$.

\begin{tabular}{|c|c|c|c|c|c|}
\hline \multicolumn{3}{|c|}{$A=30 \mathrm{~m}^{2}$} & \multicolumn{3}{|c|}{$A=35 \mathrm{~m}^{2}$} \\
\hline \multicolumn{6}{|l|}{$\beta=3 \%$} \\
\hline$\gamma_{\mu} \alpha$ & $6.7 \%$ & $10 \%$ & $\mu \quad \alpha$ & $6.7 \%$ & $10 \%$ \\
\hline $3.0 \%$ & 25 & 17 & $3.0 \%$ & 30 & 20 \\
\hline $3.5 \%$ & 30 & 18 & $3.5 \%$ & 35 & 22 \\
\hline \multicolumn{6}{|l|}{$\beta=4 \%$} \\
\hline$\gamma_{\mu} \alpha$ & $6.7 \%$ & $10 \%$ & $\mu \quad \alpha$ & $6.7 \%$ & $10 \%$ \\
\hline $3.0 \%$ & 28 & 18 & $3.0 \%$ & 33 & 21 \\
\hline $3.5 \%$ & 33 & 20 & $3.5 \%$ & 39 & 23 \\
\hline
\end{tabular}

Table 3 Number of years needed for a fixed per capita floor space in urban China 
Table 4 Housing stock and urban population under different scenarios

\begin{tabular}{|c|c|c|c|c|c|c|c|}
\hline \multicolumn{5}{|c|}{$A=30$ sq. $\mathbf{m s}$} & \multicolumn{3}{|c|}{$A=35$ sq. $\mathbf{m s}$} \\
\hline & & $\begin{array}{r}\text { Total } \\
\text { Floor } \\
\text { Space } \\
\left(\mathrm{mil} \mathrm{m}^{2}\right) \\
\end{array}$ & $\begin{array}{r}\text { Total } \\
\text { Urban } \\
\text { Population } \\
\text { (million) } \\
\end{array}$ & $\begin{array}{r}\text { Year } \\
\text { achieved }\end{array}$ & $\begin{array}{r}\text { Total } \\
\text { Floor } \\
\text { Space } \\
\left(\mathrm{mil} \mathrm{m}^{2}\right) \\
\end{array}$ & $\begin{array}{r}\text { Total } \\
\text { Urban } \\
\text { Population } \\
\text { (million) } \\
\end{array}$ & $\begin{array}{r}\text { Years } \\
\text { completed }\end{array}$ \\
\hline \multicolumn{8}{|l|}{$\beta=3 \%$} \\
\hline \multirow{2}{*}{$\alpha=6.7 \%$} & $\begin{array}{r}\mu \\
=3.0 \%\end{array}$ & 35,188 & 1,173 & 2030 & 47,591 & 1,360 & 2035 \\
\hline & $\begin{array}{r}\mu \\
=3.5 \%\end{array}$ & 46,943 & 1,565 & 2035 & 65,045 & 1,858 & 2040 \\
\hline \multirow{2}{*}{$\alpha=10 \%$} & $\begin{array}{r}\mu \\
=3.0 \%\end{array}$ & 27,777 & 926 & 2022 & 35,412 & 1,012 & 2025 \\
\hline & $\begin{array}{r}\mu \\
=3.5 \%\end{array}$ & 31,066 & 1,036 & 2023 & 41,590 & 1,188 & 2027 \\
\hline \multicolumn{8}{|l|}{$\beta=4 \%$} \\
\hline \multirow{2}{*}{$\alpha=6.7 \%$} & $\begin{array}{r}\mu \\
=3.0 \%\end{array}$ & 38,451 & 1,282 & 2033 & 52,004 & 1,486 & 2038 \\
\hline & $\begin{array}{r}\mu \\
=3.5 \%\end{array}$ & 52,046 & 1,735 & 2038 & 74,641 & 2,133 & 2044 \\
\hline \multirow{2}{*}{$\alpha=10 \%$} & $\begin{array}{r}\mu \\
=3.0 \%\end{array}$ & 28,611 & 954 & 2023 & 36,474 & 1,042 & 2026 \\
\hline & $\begin{array}{r}\mu \\
=3.5 \%\end{array}$ & 33,279 & 1,109 & 2025 & 43,046 & 1,230 & 2028 \\
\hline
\end{tabular}

Table 3 shows that when the annual growth rates of newly completed floor space and urban population are $6.7 \%$ and $3.0 \%$ respectively with a house demolition rate at $3 \%$, it will take 30 years from 2005 to construct enough housing for the urban population. It means that by 2035 , each urban resident will have a living floor space of $35 \mathrm{~m}^{2}$, with a total housing stock of 49,027 million $\mathrm{m}^{2}$. If the growth of new house construction is $10 \%$, it will require only 20 years from 2005 to meet the same target of $35 \mathrm{~m}^{2}$ per unban resident.

Table 4 shows that to meet a target of $35 \mathrm{~m}^{2}$ per urban resident and assume that the urban population growth and old house demolition rate are all 3\%, the total urban population will be 1.36 billion and a total house stock 47.6 billion $\mathrm{m}^{2}$ by 2035 .

\section{Conclusion and Policy Implications}


Housing reform commencing from 1978 has not only improved the living condition in urban China, but also made the real-estate industry become a pillar industry which contributes significantly to the country's overall economic development.

Since the second half of 2009 when the world economy gradually moved out from recession, ample liquidity and preferential policies provided by the Chinese government during crisis has heated up the housing market again. Although various adjustment policies were implemented thereafter to cool down the market, monthly sales price of 70 large- and medium-sized cities rose by $10 \%$ in the first half of 2010 . Three key factors were responsible for the housing bubble, rapid urbanization, rising income inequality, and control of land ownership by local governments.

This paper reviews the history of the Chinese housing market and urbanisation and it also defines and explains various indicators for a housing bubble in China. In particular, it provides a theoretical framework to explain that high house prices has been caused by market fragmentation caused by rising income inequality and lack of government support to the low and middle income groups.

To resolve the housing problem in China, policies must be designed to reduce house prices through reducing income inequality, providing low-cost housing for the urban poor and rural migrants working in cities, and introducing property taxes to eliminate speculation in the housing market.

\section{References}

An, H. (2008), "How the price to rent ratio influences housing price" (Chiense), Beijing Real Estate, 09:79-81.

Anderlini, J. (2009), "China Revived Property Tax to Avert Bubble", Financial Times, London, (10 December 2009).

Baker, D. (2002), "The Run-Up in Home Prices: A Bubble." Challenge 45(6):93-119.

Case, K. E. and R. J. Shiller, (2003), "Is There a Bubble in the Housing Market? An Analysis”, BPEA, 2: 299-342.

Caijing (2011), House sales decline in September among 8 large cities. http://industry.caijing.com.cn/2011-10-13/110893863.html. 
Dai, S. X. (2009), "Research on land finance and the usage of the land of local government" (Chinese), Journal of Fujian Normal University (Philosophy and Socail Science Edition), 157(4): 21-26.

Fackler, M. (2005), “Take it from Japan: Bubbles hurt”, The New York Times, http://www.nytimes.com/2005/12/25/business/yourmoney/25japan.html?_r=1\&pagew anted=all, (25 December 2005).

Feng, H. and X. J. Ni (2009), "The establishment and development of urban housing security system since the housing reform" (Chinese), Economic Research Guide, 64 (26): 194-195.

Garber, P. M. (2000), Famous First Bubbles: The Fundamentals of Early Manias, MIT Press.

Jia, K. and M. J. Liu (2007), “An analysis of issues related to China's houing reform and housing security system", Public Finance research, 7: 8-23.

Li, F. A. (2004), "The Polariation and Anti-corruption in the Economy Reform in China" (Chinese), Journal of Hubei Normal University (Philosophy and Social Science), 24(4): 22-24.

Liu, L. (2005), "Reasons behind rocketing housing price" (Chinese), Urban Development, 5:64-67.

Liu, L. (2007), "How to measure the affordabality of urban housing price in China" (Chinese), China Investment, 4:19.

Li, Y. (2007), "Housing system in urban China: A review of its historical development and future reform strategies" (Chinese), Academic Journal of Zhongzhou, 159(3): 134-136.

Pan, D. and Z. Xu (2008), "Economic Globalizatio and the Bubble of Globalization" (Chinese), Comtemporary Economy \& Management, 30 (8): 78-82.

Shiller, R. J. (2008), The Subprim Solution: How Today's Global Financial Crisis Happened, and What to Do about it, Princeton University Press: Princeton, New Jersey.

Siegel, J. J. (2003), "What Is an Asset Price Bubble? An Operational Definition”, European Financial Management, 9(1): 11-24.

SouFun.com (2009), "A decreased rental cost in Beijing", http://rent.soufun.com/rent/news/2585373.htm, (20 May 2009).

Tang, P. (2009), "How to measure housing makret bubble: An analysis based on the price to rent ratio" (Chinese), Economic and Trade Review, 03:206-207. 
The Economists, (2010), “Asia: An Odd Sort of Tax; China Mulls A property Tax", The Economists, London, (13 March 2010), 394(8673): 44.

Walder, A. (1986), Communist Neo-Traditionalism: Work and Authority in Chinese Industry, Berkeley: University of California Press.

Wang, Q. (2010), "Short-lived Buildings Creat Huge Waste", ChinaDaily, http://www.chinadaily.com.cn/china/2010-04/06/content_9687545.htm, (6 April 2010).

Wang, Y. P. and A. Murie (1999), "Commercial Housing Development in Urban China", Urban Studies, 36 (9): 1475-1494.

Wang, Y. P. (1995), "Public sector housing in urban China since 1949: the case of Xi'an" (Chinese), Housing Studies, 10: 57-82.

Wei, J. and R. Wang (2007), "The Path of China's Housing Reform: An Analysis based on the Specific Nature of Housing" (Chinese), Reform of Economic System, 2: 6-11.

Wu, F. L. (2001), “China's recent urban development in the process of land and housing marketisation and economic globalisation", Habitat International, 25(3): 273-289.

Wu, J. L. (2005), "The Prospect of Economic Development in China" (Chinese), Forward Position in Economics, 1: 4-6.

Xue, T. T. (2009), "Problems of housing supply in urban China" (Chinese), Chinese Foreign Entrepreneurs, 325(5): 101-114.

Xun, G. D. (2008), "Why Housing Price in Germany could ramian Stable over Decade" (Chinese), Journal of Party Members, 10:43.

Yao, S. J. and D. Luo (2009), 'The economic psychology of stock market bubbles in China', The World Economy, 32, (5), 667-691.

Yeh, A. G. O. and F. L. Wu (1996), "The new land development process and urban development in Chinese cities", International Journal of Urban and Regional Research, 20: 330-353.

Yuan, J. (2003), "Urban land control in China with reference to foreign experiences" (Chinese), China Real-Estate Information, 203 (5): 12-13.

Yuan, J. (2005), "Urban land allocation and regulation" (Chinese), Information of China Construction, 7: 37-40.

Zhang, Q. (2009), “30 years of housing reform: A perspective from related legislations" (Chinese), Business Law Analysis, 129 (1): 70-75. 
Zhang, Y. R. (2008), “The development of Chinese housing market during past 30 years", The Housing Industry, 12: 16-18.

Zhang, Y. J. (2009), "How economically affordable housing system reflecting the nature of housing security" (Chinese), The Housing Industry, 8: 80-82.

Zhou, M. and J. R. Logan (2002), "Market transition and the commodification of housing in urban China", in Logan, J. R ed. The new Chinese Cities, Blackwell Publisher: Oxford, UK.

Zou, B. (2009), "The Influence of Low Consumption Rate in China” (Chinese), Journal of Economic Trade in China, 16: 76-98. 